\title{
Policies as Drivers for Circular Economy in the Construction Sector in the Nordics
}

\author{
Malin zu Castell-Rüdenhausen ${ }^{1, *}$, Margareta Wahlström ${ }^{1}$, Thilde Fruergaard Astrup ${ }^{2}$, Carl Jensen ${ }^{3}$, \\ Anke Oberender ${ }^{2}$, Pernilla Johansson ${ }^{3}$ and Eirik Rudi Waerner ${ }^{4}$ \\ 1 VTT Technical Research Centre of Finland Ltd., 02044 Espoo, Finland; margareta.wahlstrom@vtt.fi \\ 2 Danish Technological Institute, 2630 Taastrup, Denmark; thas@teknologisk.dk (T.F.A.); \\ aob@teknologisk.dk (A.O.) \\ 3 RISE Research Institutes of Sweden, 50115 Borås, Sweden; carl.jensen@ri.se (C.J.); \\ pernilla.johansson@ri.se (P.J.) \\ 4 Multiconsult, 0213 Oslo, Norway; EirikRudi.Waerner@multiconsult.no \\ * Correspondence: malin.castell@vtt.fi
}

check for updates

Citation: zu Castell-Rüdenhausen, M.; Wahlström, M.; Astrup, T.F.;

Jensen, C.; Oberender, A.; Johansson, P.; Waerner, E.R. Policies as Drivers for Circular Economy in the Construction Sector in the Nordics. Sustainability 2021, 13, 9350. https://doi.org/10.3390/su13169350

Academic Editors: Roberto Zoboli,

Massimiliano Mazzanti and

Simone Tagliapietra

Received: 31 May 2021

Accepted: 16 August 2021

Published: 20 August 2021

Publisher's Note: MDPI stays neutral with regard to jurisdictional claims in published maps and institutional affiliations.

Copyright: (c) 2021 by the authors. Licensee MDPI, Basel, Switzerland. This article is an open access article distributed under the terms and conditions of the Creative Commons Attribution (CC BY) license (https:/ / creativecommons.org/licenses/by/ $4.0 /)$.

\begin{abstract}
A circular economy (CE) represents the key alternative to the linear 'take-make-consumedispose' economic model, that still predominates in the construction sector. This study investigates how policies support CE-focused businesses in the construction sector in the Nordics. A literature review, the creation of a database, a review of Nordic actors with a CE focus, and targeted interviews with actors across the value chain of the construction sector in Denmark, Finland, Norway, and Sweden enabled us to benchmark the CE policy landscape and assess how CE policies at different levels support $\mathrm{CE}$ business models in the construction sector. The results show that the construction sector is well represented in the CE policy frameworks and that many business opportunities are created when national and local policies are put into practice. The implementation of policies is mainly done via three key concepts, i.e., planning, requirements for sustainable constructions, and requirements for public procurement. It can be concluded that policies are drivers for the implementation of a CE and support CE business models in the Nordics.
\end{abstract}

Keywords: construction sector; circular economy; policies; recycling; reuse

\section{Introduction}

In the past, and still today, the construction industry practices a non-sustainable, linear economic model, based on the idea of "take, make, dispose of" [1]. The linear model does not support constructions and elements being deconstructed and reused, but they become obsolete at the end-of-life of the building [2]. The linear model assumes that natural resources are abundant, but now the world is in some cases exceeding the planetary boundaries, showing the need for a transition to a circular economy (CE) [3].

Construction and demolition waste (C\&DW) accounts for more than $30 \%$ of the waste generated in the European Union [4]. Today, the recovery rate of mineral C\&DW (excluding waste soils) is rather high in all the Nordic countries (especially Denmark and Finland) [5]. However, high recovery rates are, to a large extent, based on a high degree of backfilling or low-grade recovery, such as using recycled aggregates in road sub-bases (downcycling) [3].

The transition to $\mathrm{CE}$ requires a change in both attitudes and the core structure of an industry [6]. Much is already known about the drivers and barriers for implementing the changes. Drivers and barriers related to recycling C\&DW have been presented by, e.g., Williams 2020 [7], Wahlström et al., 2020 [3], Wahlström et al., 2019 [8], Bio by Deloitte et al., 2017 [9], Kirchherr et al., 2017 [10], Miljøstyrelsen 2019 [11] and previous European Union (EU) funded projects (EU HISER [12]; EU IRCOW [13]). The key barriers presented in these studies are related to the design and construction of buildings reusing materials and components, and recycling waste materials. The CE business models of the construction 
sector have been presented in earlier Nordic studies (Høibye \& Sand 2018 [14]; MunckKampmann et al., 2018 [15]; Alhola et al., 2017 [16]). In these studies, policies have been identified as a key driver by setting the recycling targets for the sector.

In order to speed up the transition to a CE in the construction sector, more knowledge is needed on how companies can be supported in practice. There is limited literature on how companies with a CE business model benefit from the current policy framework and which policy instruments are seen by the companies as advancing their activities.

This study aims to understand the policy landscape and the role of policies in the transition toward a CE in the construction sector in the Nordics. More specifically, the objectives of the study were (i) to benchmark the national and local CE policy framework in the Nordic countries and investigate whether the construction sector is addressed, (ii) to build a database of $C E$ actors along the circular value chain in the construction sector in the Nordics, to (iii) review actors with a CE business idea to identify links to national and local policies, (iv) to identify key drivers and barriers related to the successful implementation of $\mathrm{CE}$ business models, and finally (v) to evaluate if the national and local CE policies support the transition to a $\mathrm{CE}$ in the construction sector in practice.

The article is structured as follows: The introduction section describes the status and presents the knowledge gap of the field of CE in the construction sector. Additionally, the objectives of the study are presented in the introduction. The background section describes the lifecycle value chain of the construction sector, as well as the European CE policy framework, and how the literature presents the impact of policies on the operational environment in CE actors of the construction sector. The materials and methods section presents the CE policy framework in Denmark, Finland, Norway, and Sweden, the CE criteria used for benchmarking CE activities in this study, and also the evaluation criteria for selecting companies for identifying the links to policies, drivers, and barriers related to the business model. The results section contains the findings of the analysis on how the policies influence the implementation of CE concepts at different levels in the Nordics. Finally, the discussion section concludes the article with some remarks related to the methodology and results presented in previous sections.

\subsection{Background}

CE represents the key alternative to the linear 'take-make-consume-dispose' economic model, that still predominates in the construction sector [17]. The Ellen McArthur Foundation defines $\mathrm{CE}$ to be 'restorative and regenerative by design, aiming to keep products, components, and materials in a closed loop and at their highest value at all times, also distinguishing between the technical cycle (finite materials) and biological cycle (renewable materials)' [1]. The CE in the construction sector is presented from a material perspective by Afshari and Górecki [18], where after the end-of-life building materials should be reused and their components and parts deconstructed, to act as material banks for new buildings, keeping the components and materials in a closed loop.

When closing the loop, all stages of the value chain play an important role; from design to end-of-life. C\&DW is generated throughout the life cycle of buildings, also indirectly via the planning and design phase; when there is a lack of consideration on waste management and waste reduction in earlier phases of a project, it will reflect the total waste generation during the whole life cycle [19]. Most C\&DW is generated at the end-of-life, since most building materials and components do not have a potential for reuse [20]. This study considers the five stages of a building's life cycle used by the European environmental agency [17], i.e., (i) recycling and product manufacture; (ii) design; (iii) construction; (iv) use and maintenance; and (v) end-of-life and demolition.

Wahlström et al. [21] defines the key features of the five stages of the value chain as follows: (i) the design phase facilitates sustainable material use, maintenance requirement, easy change of intended use, and expected lifespan, (ii) the construction phase is key to material efficiency and construction waste management, (iii) the use and maintenance phase determines the lifespan realization, (iv) the end-of-life and demolition phase determines the 
fates of the generated waste materials, and (v) recycling and the production of construction materials and products closes the material loop of the construction sector.

\subsection{The European Policy Framework}

The basic principles and general ambitions for $\mathrm{CE}$ in the construction sector are defined in the European CE policy framework [22-24]. EU legislation and policies are transposed into national legislation and policies, thus forming the basis for the CE policy framework in EU Member States. EU policies set the framework both for recycling targets for waste [22] and for market demand for secondary materials [23].

The first Circular Economy Action Plan (CEAP) of the EU defines construction and demolition as a priority area in the EU for closing the material loops and promoting a CE [24]. The second CEAP of the EU calls for improved recyclability, but also for the use of secondary materials in products [23]. The ambition for increased recycling is transposed into the revised Waste Framework Directive (WFD 2008/98/EC, amended 2018/851) by setting a mandatory target for the recovery of C\&DW of 70 per cent as of 2020 [22].

The European Green Deal lays down the key framework for the policies of the construction sector [25], and the Renovation Wave states key initiatives to, e.g., increase reuse and recycling in the construction sector [26]. Furthermore, the second CEAP presents initiatives to propose minimum mandatory green public procurement (GPP) criteria as a means to enhance circularity in the EU, as well as key principles for the construction sector to increase material efficiency and promote CE [23].

Aiming for sustainability in the building sector may increase recycling, as materials with recycled content are often given credit in environmental rating protocols. Examples of well-established protocols are: Level(s) from the European Commission [27], the Building Research Establishment Environmental Assessment Method (BREEAM) from the UK's BRE [28], and the US Green Building Council's Leadership in Energy and Environmental Design (LEED) [29]. The protocols can be used by investors, designers, general contractors and real estate operators for proving the sustainability of a building.

Achieving CE targets in waste management is often measured based on the recycling rate, which is calculated as the ratio of recycled waste to the generated waste [30,31]. There is no distinction between preparation for reuse, high-grade recycling, and downcycling (including backfilling) [30]. The Waste Framework Directive sets a target of recycling $70 \%$ (by weight) of non-hazardous construction and demolition waste [22]. By 2024, the Commission shall consider material-specific targets for key streams of C\&DW [22]. A recycling target for an entire industry creates incentives to recycle materials that have a large impact on the recycling rate and risks reducing the incentives to recycle materials that have a small impact but may be more valuable [21].

\subsection{Policy Impact on the Operational Environment}

Local CE drivers are created through setting targets and responsibilities in local strategies, by formulating CE guidelines and by setting specific requirements for construction projects. Local policy documents are often a continuation of the national policy framework with similar targets, often including more detailed practices and responsibilities for reaching the targets. Local CE policies are based on local needs and local prospects, aiming to have a local impact, but also to contribute to reaching the targets set by national and EU CE policies. [32] Kirchherr et al. (2017) identifies four key barriers to the CE, i.e., regulatory, culture, technology, and market barriers [10]. However, the same study also identifies policy-makers as the key actors in breaking the barriers and facilitating the transition to a CE via CE-friendly policies.

Recycling targets for C\&DW are set both in the Waste Framework Directive [22], transposed to the national legislation or the waste management plan of the Nordic countries [33-36]. Recycling targets are a key policy for increasing recycling, but also for the use of secondary raw materials and closing the material loop [14-16]. Policies can influence recycling rates via, e.g., taxes for landfilling, taxes on virgin materials, encouragement of 
GPP, end-of-waste criteria, and extended product responsibility or product ownership, supporting the attaining of recycling targets, and other CE activities as well. [3]

Related to recycling and reuse, construction products containing recovered materials need to comply with product requirements, which do not differentiate between virgin and recovered materials. The Construction Products Regulation (305/2011/EU) requires that all construction products put on the market be CE-marked [37], requiring full knowledge of the material content. This can be hard to acquire for waste feedstock, which is considered one of the key barriers for these activities [14].

Green public procurement (GPP) has a significant leverage for addressing environmental challenges. The European Commission (EC) has supported this strategic approach by publishing a Communication [38], a GPP handbook [39], and EU GPP criteria to support sustainability in public tendering [40]. The EC has identified the construction sector as a priority sector for GPP; a sector where GPP can significantly contribute to improving the environmental performance [38].

GPP can facilitate sustainability in construction by promoting closed material loops via the reuse, remanufacturing, and recycling of products and materials, also avoiding their harmful environmental impact. GPP can set requirements on the use of wastederived materials and thus promote the markets for secondary raw materials and reusable construction products. In demolition, GPP requirements on the reuse and recycling of construction and demolition waste in new construction products will boost the market for recovered materials. [16] The public sector is the key property developer in the Nordics [14], and by using GPP criteria, the public sector can have a great impact on the competitiveness of CE-focused companies [16].

As an example, to support innovative and sustainable public procurement in Finland, the Finnish Government launched KEINO, a competence centre for sustainable and innovative public procurement. KEINO aims to improve the effectiveness and quality of public procurement and public services [41]. In Finland, a guideline for Public Green Procurement in demolition was published in 2019 by the Finnish Ministry of the Environment, intended to be used by municipalities to improve the recycling of C\&DW arising from the demolition of public buildings [42].

\section{Materials and Methods}

\subsection{CE Criteria and Indicators}

CE criteria presented in Table 1 are employed to enable the identification of CE policies and business models. $C E$ criteria also enable benchmarking policies in relation to $C E$ focus to give an overview of the CE policy framework in the Nordics. The indicators presented in this study are chosen and modified to best fit the construction sector and excludes topics related to investments, markets, and trade, with a focus on material streams in the construction sector. The CE indicators presented in Table 1 are collated from indicators used by the European Commission [43], EUROSTAT [44], and Moraga et al. [45].

\subsection{Policy Framework}

In order to set the scene and benchmark the Nordic countries, national strategies for CE were shortly reviewed to compare the national policy framework in the Nordics, as well as to check the transposition of EU's CE policies into national policies in the Nordics. Although Norway is not a Member State of the EU, many policies are transposed from the European policy framework into Norwegian policies and legislation.

The CE policies in the Nordics aim to transpose the European CE policy framework. Waste management and waste prevention plans are mandatory, as stated in the Waste Framework Directive [22]. Finland, Norway, and Sweden have integrated the Waste Prevention Plans into the Waste Management Plans [46-48]. Other strategies with a CE relevance or relevant to the construction sector and CDW represent several different types of documents. The national CE policy frameworks were examined through 24 policy 
documents, such as strategies and roadmaps. The list of policies is presented in Table 2 in the results section.

Table 1. CE criteria and indicators used for the assessment of the CE focus of policies and business models.

\begin{tabular}{|c|c|}
\hline CE Criteria & CE Indicator \\
\hline \multirow{5}{*}{ 1. Reducing use of resources } & 1.1 Sharing of facilities/adaptive use of facilities prevents the need for additional buildings \\
\hline & 1.2 Increasing the utilization rate of buildings to prevent the need for additional buildings \\
\hline & 1.3 Choice of material or product for options requiring less material for the same performance \\
\hline & 1.4 Saving of materials in production, optimizing cut-offs \\
\hline & 1.5 Reducing material consumption at construction site by using products pre-cut to size \\
\hline \multirow{3}{*}{ 2. Waste prevention } & 2.1 Extending life span by renovating old buildings instead of building new ones \\
\hline & $\begin{array}{l}\text { 2.2 Preventing premature demolition by changing the use of a building } \\
\text { 2.3 Repair and maintenance to prevent premature demolition }\end{array}$ \\
\hline & $\begin{array}{l}\text { 2.4 Use of demountable construction components enabling the reuse of construction } \\
\text { components and reconstruction of buildings }\end{array}$ \\
\hline 3. Increasing recycling rates & $\begin{array}{l}\text { 3.1 Sorting, separating, and recycling activities } \\
\text { 3.2 Enabling recycling through selective demolition } \\
\text { 3.3 Use of waste-derived/recycled materials in new products } \\
\text { 3.4 Use of waste-derived materials in construction }\end{array}$ \\
\hline $\begin{array}{l}\text { 4. Use of biobased/renewable } \\
\text { materials }\end{array}$ & 4.1 Biobased construction materials or products, such as wood, cellulose, cotton \\
\hline 5. Use of recyclable materials & $\begin{array}{l}\text { 5.1 Using materials that are recyclable at end-of-life } \\
\text { 5.2 Enabling clean dismantling and recycling at end-of-life by not mixing materials at the } \\
\text { installation phase }\end{array}$ \\
\hline
\end{tabular}

Table 2. The national CE policy framework in the Nordic countries. Finland and Norway have integrated the Waste Prevention Plans into the Waste Management Plans. Other strategies with a CE relevance or relevant to the construction sector and CDW are not specifically defined and can represent several different types of documents, and thus the list is not exhaustive.

\begin{tabular}{|c|c|c|c|c|c|c|c|}
\hline \multirow[t]{2}{*}{ Focus of National Strategies } & \multicolumn{2}{|c|}{$\begin{array}{c}\text { Focus on the } \\
\text { Construction Sector * }\end{array}$} & \multicolumn{5}{|c|}{ CE Criteria Focus ** } \\
\hline & 1. & 2. & 1. & 2. & 3. & 4. & 5. \\
\hline \multicolumn{8}{|l|}{ Denmark } \\
\hline National Waste Management Plan $[49,50]$ & $\mathrm{x}$ & $\mathrm{x}$ & & & $\mathrm{x}$ & & \\
\hline National Waste Prevention Plan [51] & $\mathrm{x}$ & $\mathrm{x}$ & & $\mathrm{x}$ & & & \\
\hline \multicolumn{8}{|c|}{ Other strategies with a CE relevance or relevant to the construction sector and CDW } \\
\hline - $\quad$ Strategy for circular economy [52] & $\mathrm{x}$ & $\mathrm{x}$ & & & $\mathrm{x}$ & & \\
\hline - $\quad$ Strategy for intelligent public procurement [53] & & & & & & $\mathrm{x}$ & $\mathrm{x}$ \\
\hline - $\quad$ The Government's action plan on plastics [54] & & $\mathrm{x}$ & & $\mathrm{x}$ & $\mathrm{x}$ & & \\
\hline - $\quad$ Strategy for digital construction work [55] & $\mathrm{x}$ & $\mathrm{x}$ & & & $\mathrm{x}$ & & \\
\hline \multicolumn{8}{|l|}{ Finland } \\
\hline National Waste Management Plan [46] & $\mathrm{x}$ & $\mathrm{x}$ & & $\mathrm{x}$ & $\mathrm{x}$ & & \\
\hline \multicolumn{8}{|c|}{ Other strategies with a CE relevance or relevant to the construction sector and CDW } \\
\hline - $\quad$ National circular economy programme [56] & $\mathrm{x}$ & & & $\mathrm{x}$ & $\mathrm{x}$ & & $\mathrm{x}$ \\
\hline - $\quad$ Material efficiency programmes $[57,58]$ & $x$ & $\mathrm{x}$ & $\mathrm{x}$ & $x$ & $x$ & & \\
\hline - $\quad$ Demolition guidelines $[42,59]$ & $\mathrm{x}$ & & & $\mathrm{x}$ & $\mathrm{x}$ & & \\
\hline - $\quad$ Plastics roadmap [60] & $\mathrm{x}$ & $\mathrm{x}$ & $\mathrm{x}$ & & $x$ & & \\
\hline - $\quad$ Wood Building Program [61] & $\mathrm{x}$ & $\mathrm{x}$ & & & & $\mathrm{x}$ & \\
\hline
\end{tabular}


Table 2. Cont.

Focus of National Strategies

\begin{tabular}{ccccccc}
$\begin{array}{c}\text { Focus on the } \\
\text { Construction Sector }\end{array}$ & \multicolumn{5}{c}{ CE Criteria Focus ** } \\
\hline 1. & 2. & 1. & 2. & 3. & 4. & 5. \\
\hline
\end{tabular}

Norway

Sweden

National Waste Management Plan [47]

$x \quad x$

Other strategies with a CE relevance or relevant to the construction sector and CDW

- National action plan for construction and demolition waste 2017-2020 [62]

- Circular economy recommendations from the industry [63]

- Governmental CE policy framework [64]

$\begin{array}{cccc}\text { X } & & x & x \\ x & & & x \\ & x & x & x\end{array}$

National Waste Management Plan [48]

$x \quad x$

Other strategies with a CE relevance or relevant to the construction sector and CDW

- Circular economy strategy [65]

- $\quad$ Resource and waste guidelines for construction and demolition [66]

- $\quad$ Roadmap to a fossil free competitiveness-construction and civil engineering sector [67]

- $\quad$ Focus on wood construction [68] $\mathrm{x}$

$\mathrm{X}$

$x$

$x \quad x$

$\mathrm{X}$

$x$

$x+x$

*1. A specific section dedicated to construction and demolition waste (CDW); 2. Objectives or targets with respect to the construction sector and/or CDW. ** 1. Reducing the use of resources; 2 . Waste prevention; 3 . Increasing recycling rates; 4 . Use of biobased/renewable materials; 5 . Use of recyclable materials.

The assessment of local policies aimed to facilitate the understanding of how national policies are put into practice on a local level. The policies examined were not explicitly CE strategies, but represented the concept of sustainability and CE. The policy documents were benchmarked against the CE criteria presented in Table 1 to confirm their CE focus. CE policies on a local and regional level were examined through 18 policy documents, such as strategies, roadmaps, and networking activities. The list is found in Appendix A.

\subsection{Identification of Links to National and Local CE Strategies}

A database was created identifying actors of the Nordic construction sector with a CE focus in their business model. The database presents a short description of the business idea of each actor, as well as information on the life cycle phase and CE focus. The database is expandable and updateable. For this assessment, 113 actors from Denmark, Finland, Norway, and Sweden were identified by the authors and represent companies with CE activities in the construction sector, as well as actors actively networking in CE events such as attending conferences and expert group meetings in the construction sector in the Nordics. The database is not exhaustive and can be easily expanded.

The companies of the database have been characterized with respect to life cycle phase and CE criteria to identify where the key actors are focusing their activities. The representation of the five stages of a building's life cycle used by the European Environmental Agency [17] is illustrated in Figure 1, i.e., (i) recycling and product manufacture; (ii) design; (iii) construction; (iv) use and maintenance; and (v) end-of-life and demolition, where one actor can represent more than one stage of a builing's life cycle. The representation of the CE criteria as presented in Table 1, where one actor can focus on more than one CE criteria, is illustrated in Figure 2.

To better understand the links between policies and CE business models, 14 actors from the database representing different stages of the value chain were further assessed to identify links to national and local CE strategies. Actors were chosen from all four Nordic countries to facilitate comparison among the Nordic countries, and selected based upon the relative strength of the business idea focus on CE (as presented in Table 1). Based on these criteria, 14 actors were chosen for further analysis of the links to national and local strategies. 


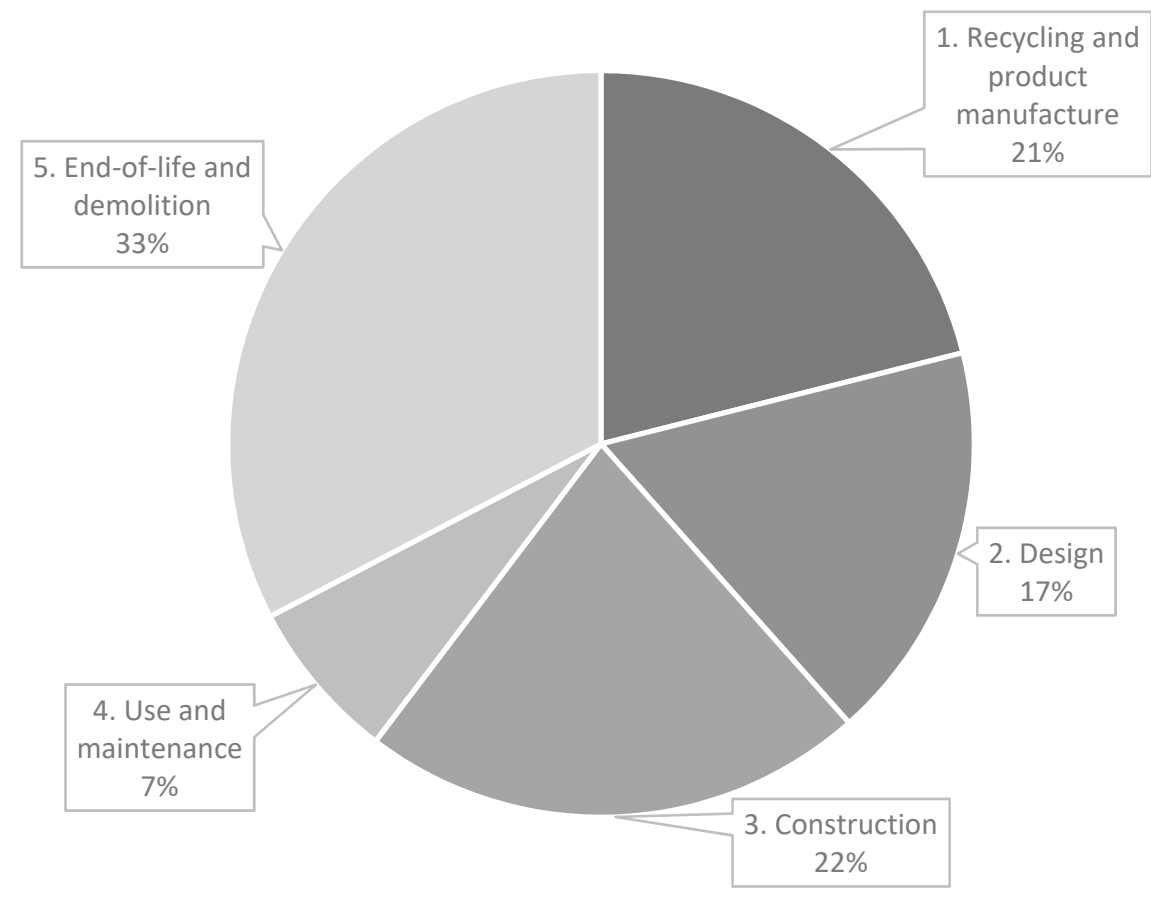

Figure 1. The representation of the companies of the database in respect to the life cycle phase. The database contains 113 companies, and one company can represent more than one stage of a building's life cycle.

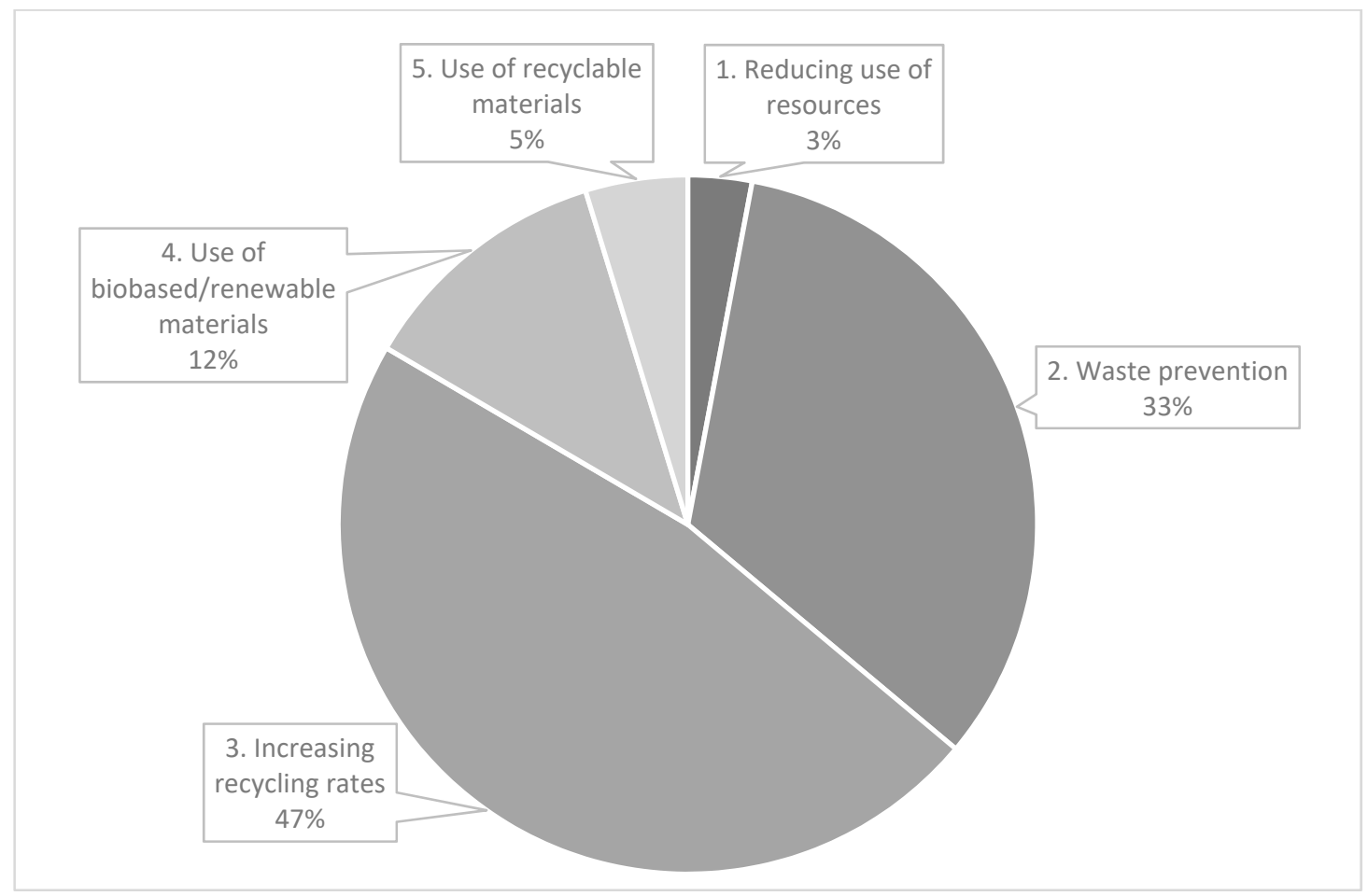

Figure 2. The representation of the companies of the database in respect to the CE criteria. The database contains 113 companies, and one company can address more than one CE criteria.

In order to gain further understanding of the barriers and drivers to the implementation of CE business models in the construction sector, in-depth interviews were conducted with 10 of the companies that had been reviewed. In the interviews, links to national 
and local strategies were identified, and the key barriers for the business models were also identified. Finally, the interviews aimed at exploring why the selected companies are successful in overcoming these barriers and what the role of different level policies and strategies is for their business models, aiming to evaluate if the policies support the transition to a CE in the construction sector in practice. In all interviews, one or more representatives of the companies were present. The interviews were structured to focus on how national and local policies act as barriers to, and drivers of, the specific company in their business. All interviews followed a similar protocol, although conducted by different members of the team.

\section{Results}

\subsection{Policies}

The review of the national CE policy framework in the Nordic countries shows that the construction sector is well represented in CE policies on a national level, both in the mandatory waste management and prevention plans, as well as in other strategies. All countries present objectives or targets for the construction sector in different level policies. Furthermore, the study showed that the national policy scene in all countries was somewhat similar in respect to target setting and objectives. The benchmarking of the national policies is illustrated in Table 2. Finland, Norway, and Sweden have integrated the Waste Prevention Plans into the Waste Management Plans [46-48]. Other strategies with a CE relevance or relevant to the construction sector and CDW can represent several different types of documents, and thus the list is not exhaustive.

The evaluation of local policies found that the transition to a CE is well presented in the local policy framework in the Nordics - mainly incorporated into a general municipal strategy, but also as free-standing strategies for sustainability and CE. The list is found in Appendix A. Local strategies often included more detailed practices and responsibilities for reaching the targets, where national policies were more general. Local strategies and guidelines can also entail a more practical follow-up system for ensuring compliance with the set targets.

It was found that municipalities use mainly three key policies for supporting CE business models and meeting their $\mathrm{CE}$ targets, i.e., planning, requirements for sustainable constructions, and requirements for public procurement. As the planning and permitting of construction and demolition activities are under municipal control, local strategies and guidelines give the municipalities a good tool for creating incentives to move towards more circular business models. Some municipalities are actively involved in construction activities, allowing them to highly impact project details in construction via GPP.

The study found that municipalities set requirements on CE solutions in construction with a high focus on end-of-life activities. The requirements of the demolition phase focus on resource mapping prior to demolition, the use of selective demolition, as well as the reuse and recycling of waste. CE solutions in the construction phase focus mainly on the use of materials that are recyclable, dismantlable, and also on the documentation of material content, e.g., in material passports, all with an emphasis on forthcoming end-oflife activities.

Good examples of steering via policies are the City of Helsinki and the City of Copenhagen. Helsinki uses public procurement in construction combined with planning to set requirements supporting the local sustainability strategy. In the "The Carbon-neutral Helsinki 2035 Action Plan", the city sets clear targets for emissions reduction and defines clear measures to reach the set targets [69]. In 2020 the City of Copenhagen decided that Byggeri København, a major developer for Copenhagen, would address CE in all construction projects. The City of Copenhagen has developed guidelines to support and facilitate the implementation of the local CE strategy and setting requirements for sustainable constructions [70]. 


\subsection{Identification of Links to National and Local CE Policies}

Based on predefined criteria, 14 actors were chosen for a deeper analysis of the circular value chain of the construction sector. The actors chosen in this report all have a CE focus in their activities and contribute to a rethinking of the traditional value chain. The actors were characterized with respect to the life cycle phase, and it was found that most activities were related to the construction and end-of-life phases. The actors' link to the policies, the position in the value chain of the construction sector, and the CE criteria in focus are presented in Table 3. The business focus of the actors are presented in Appendix B.

Table 3. Assessment of the actors in response to strategies, value chain, and CE criteria.

\begin{tabular}{|c|c|c|c|c|c|c|c|c|c|c|c|}
\hline \multirow{2}{*}{ Actor nr. } & \multirow{2}{*}{ Identified Link to Policy Document } & \multicolumn{5}{|c|}{ Phase of Value Chain * } & \multicolumn{5}{|c|}{ CE Focus ** } \\
\hline & & 1. & 2. & 3. & 4. & 5. & 1. & 2. & 3. & 4. & 5. \\
\hline 1. & $\begin{array}{l}\text { National CE policy } \\
\text { Not linked to local policy level }\end{array}$ & & & $\mathrm{x}$ & & $\mathrm{x}$ & & $x$ & $\mathrm{x}$ & & \\
\hline 2. & $\begin{array}{l}\text { National waste management/prevention plan } \\
\text { National CE policy } \\
\text { Not linked to local policy level }\end{array}$ & & & $\mathrm{x}$ & & $x$ & & $x$ & $\mathrm{x}$ & & \\
\hline 3. & $\begin{array}{l}\text { National waste management/prevention plan } \\
\text { National CE policies } \\
\text { Local CE strategies }\end{array}$ & $\mathrm{x}$ & $\mathrm{x}$ & $\mathrm{x}$ & & $\mathrm{x}$ & & $x$ & $\mathrm{x}$ & $x$ & \\
\hline 4. & $\begin{array}{l}\text { National waste management/prevention plan } \\
\text { Not linked to local policy level }\end{array}$ & $\mathrm{x}$ & & & & $\mathrm{x}$ & & & $\mathrm{x}$ & & \\
\hline 5. & $\begin{array}{l}\text { National waste management/prevention plan } \\
\text { Not linked to local policy level }\end{array}$ & $\mathrm{x}$ & & $\mathrm{x}$ & & $x$ & & & $\mathrm{x}$ & & \\
\hline 6. & $\begin{array}{l}\text { Indirectly linked to national CE policies } \\
\text { Local CE strategies }\end{array}$ & & $\mathrm{x}$ & $\mathrm{x}$ & $\mathrm{x}$ & $x$ & & $x$ & $\mathrm{x}$ & & \\
\hline 7. & $\begin{array}{l}\text { National waste management/prevention plan } \\
\text { Local CE strategies }\end{array}$ & & & $\mathrm{x}$ & & $x$ & & $\mathrm{x}$ & $\mathrm{x}$ & & \\
\hline 8. & $\begin{array}{l}\text { National waste management/prevention plan } \\
\text { National CE policy } \\
\text { Not linked to local policy level }\end{array}$ & & & & & $x$ & & & $\mathrm{x}$ & & \\
\hline 9. & $\begin{array}{l}\text { National waste management/prevention plan } \\
\text { National CE policies } \\
\text { Not linked to local policy level }\end{array}$ & & $x$ & $x$ & $x$ & & $x$ & $x$ & & $x$ & \\
\hline 10. & $\begin{array}{l}\text { National waste management/prevention plan } \\
\text { National CE policy } \\
\text { Not linked to local policy level }\end{array}$ & $x$ & & $x$ & & $x$ & & & $x$ & & $x$ \\
\hline 11. & $\begin{array}{l}\text { Indirectly linked to national CE policies } \\
\text { Local CE strategies }\end{array}$ & & & $x$ & $x$ & $x$ & & $x$ & $x$ & & \\
\hline 12. & $\begin{array}{l}\text { National waste management/prevention plan } \\
\text { Not linked to local policy level }\end{array}$ & & & $x$ & & $x$ & & $x$ & & & \\
\hline 13. & $\begin{array}{l}\text { National waste management/prevention plan } \\
\text { National CE policy } \\
\text { Local CE strategies }\end{array}$ & & & $x$ & & $x$ & & $x$ & $x$ & & \\
\hline 14. & $\begin{array}{l}\text { National waste management/prevention plan } \\
\text { National CE policy } \\
\text { Not linked to local policy level }\end{array}$ & & & $x$ & & $x$ & & $x$ & $x$ & & \\
\hline
\end{tabular}

* 1. recycling and product manufacture; 2 . design; 3 . construction; 4. use and maintenance; 5 . end-of-life and demolition; ${ }^{* *} 1$. reducing use of resources; 2 . waste prevention; 3 . increasing recycling rates; 4 . use of biobased/renewable materials; 5 . Use of recyclable materials.

Most of the reviewed actors had a CE focus on waste prevention and recycling. Only one company had a focus on the reducing use of resources, one had a focus on the use of recyclable materials, and two on the use of biobased/renewable materials. This shows that 
the $\mathrm{CE}$ focus of the reviewed actors is strongly on waste and less on materials and products. Actors 3, 9, and 10 have a product-minded focus: 3 and 9 using wood as raw material; 9 focusing on optimizing material use and reducing the use of resources; and 10 closing the loop using recyclable raw materials.

Waste prevention is on the top of the waste hierarchy [22], and a key CE criterion. Several of the actors focus on the reuse of building materials and the prevention of waste generation. National waste management and prevention plans and CE policies emphasize the importance of waste prevention.

Recycling was represented in all business models except two, being the most common $\mathrm{CE}$ criteria for the actors. Recycling represents a well-implemented CE business model and is also well represented in local and national CE policies (see Table 2 and Appendix A).

\subsection{Drivers and Barriers for CE Business Activities}

Ten focus interviews were conducted to increase the knowledge on how policies have supported the establishment of businesses with a CE focus. The evaluation of local and national policies clearly illustrated how policy instruments can drive CE initiatives. This was also highlighted during in-depth discussions with company representatives, who noted how particular national and local CE policies incentivized CE actions and supported their own business model. The interviews confirmed the results of the assessment presented in Table 3, accenting that the transposing of national recycling targets into local CE strategies with a subsequent implementation through GPP requirements for public construction projects provides a leverage for companies involved in recycling and the utilization of secondary materials.

In the interviews it was highlighted that GPP is a key driver for CE business models. GPP can promote recycling and the use of secondary raw materials and reusable construction products. GPP is needed both in construction and in demolition. Identified barriers related to GPP criteria for secondary raw materials related to the market's readiness; some difficulties were identified related to the supply of high-quality secondary materials, complying with the requirements of both the property developer and the contractor. The lack of information on how to set realistic GPP requirements for recycling and reuse options was highlighted in one interview.

Three interviews disclosed that there is often a lack of information among stakeholders on the availability of recovered and reusable materials and components. There is a need to streamline the reuse processes to make the reusable products and recovered materials easily accessible. This requires, e.g., comprehensive reuse inventories and providing storage solutions. The logistics in dismounting products from buildings must be synchronized with the delivery for reuse. If not, the storage creates extra costs. To enable this, a better coverage of online digital marketplaces for a business-to-business exchange of waste and the production side-streams for this type of CE business models need to evolve.

The material availability is also presented as an important aspect to be considered. In one interview, it was highlighted that mineral waste cannot be transported far from the demolition site without increasing costs and environmental impacts.

The importance of the effective identification, sorting, and collection of building materials to support the security of supply was highlighted in two interviews. Dismantling reusable products, structures, and elements prior to demolition delays the demolition process and increases storage needs and demolition costs.

Doubts about quality (especially fluctuations in the quality of recovered materials) were highlighted in all interviews as one key barrier for recycling. Concerns about the quality of the waste, such as impurities and material degradation, and the potential presence of hazardous materials, such as paint and glues, may cause a safety concern for the recovered waste streams, especially if a tight quality-control system is not applied.

Construction products containing recovered materials need to comply with product requirements, which do not differentiate between virgin and recovered materials. In two interviews, the requirement of the CE-marking of construction products put on the 
market (as stated in the Construction Product Regulation [37]) was seen as a driver for businesses. Having access to the required data has enabled them to turn this hinder into a driver.

In all interviews there was a consensus that the main obstacle for the reuse and recycling of C\&DW is economic, due to the price of secondary raw materials and used products often exceeding the price of virgin raw materials and new products (e.g., aggregate, wood, glass, and gypsum). In Finland, Norway, and Sweden, the abundance of wood and aggregate, in particular, limit the interest in recycling these materials. In two interviews, it was pointed out that landfilling is seen as a more cost-effective solution for the demolition company. In addition, there are extra costs from the sorting of the waste into a fraction that is clean enough to meet the quality demands of the producer of the secondary raw material.

The environmental aspects and reduced costs for waste disposal were recognized as incentives and drivers for increased reuse in all interviews. Still, in one interview, it was emphasized that the financial, social, and organizational barriers of reuse were found to be more difficult to overcome compared to the technical barriers. Awareness and competence in reuse must be increased throughout the value chain for reuse aspects to be considered earlier in the process.

In two interviews, the lack of numerical indicators for all CE criteria was considered a bottleneck. Achieving CE targets is often measured based only on the recycling rate, a numerical indicator used in waste management reporting. There are currently no numerical indicators for waste prevention, even if waste prevention highly supports the CE goals. It is unclear how to address the avoided waste generation, as there is currently no system to report waste prevention in environmental reporting.

One interview highlighted that digitalization is a key driver for circularity. However, digitalization and digital tools cannot stand alone, as they also depend on the stakeholders' acceptance and use of the tools to be effective. Digitalization may play an important role in supporting the flow of information and the traceability of waste, i.e., the origin and treatment of waste, which is crucial for the guarantee of safety and the quality of the waste.

While policies are key to raising awareness, they also need to be followed up by concrete initiatives that ensure implementation in practice. Two interviews highlighted the need for funding programs and initiatives that promote new business start-ups and other entrepreneurial initiatives for bringing ideas to the market.

The drivers and barriers identified in this study all relate to the business models of the companies that were interviewed. It can be concluded that all companies stated that the current policy landscape support, to some extent, their CE activities. The key drivers and barriers related to the successful implementation of CE business models identified in the interviews are summarized in Table 4.

Table 4. Summary of drivers and barriers identified related to the successful implementation of CE business models.

\begin{tabular}{cll}
\hline Topic & \multicolumn{1}{c}{ Driver } & \multicolumn{1}{c}{ Barrier } \\
\hline Green Public Procurement (GPP) & $\begin{array}{l}\text { Promotes recycling and the use of } \\
\text { secondary raw materials and } \\
\text { reusable construction products. }\end{array}$ & $\begin{array}{l}\text { Lack of information on how to set realistic GPP } \\
\text { requirements. }\end{array}$ \\
\hline
\end{tabular}

Material availability/security of supply

Lack of information on

forthcoming material availability

Doubts about quality
Supply and demand do not meet or the distances are too long.

Dismantling delays the demolition process and increases costs.

Dismounting must be synchronized with the delivery for reuse, otherwise storage costs will arise.

Concerns about the quality of the waste may cause a safety concern for the recovered waste streams.

The price of secondary materials and products often exceed the price of virgin. 
Table 4. Cont.

\begin{tabular}{|c|c|c|}
\hline Topic & Driver & Barrier \\
\hline Cost-efficiency of recycling & & Landfilling is seen as more cost-efficient than recycling. \\
\hline $\begin{array}{l}\text { Lack of numerical indicators for } \\
\text { all CE criteria }\end{array}$ & & $\begin{array}{l}\text { Lack of numerical indicators to report waste prevention } \\
\text { in environmental reporting. }\end{array}$ \\
\hline Digitalization & $\begin{array}{l}\text { Supports the flow of information } \\
\text { and the traceability of waste. }\end{array}$ & \\
\hline $\begin{array}{l}\text { Access to waste data } \\
\text { and traceability }\end{array}$ & $\begin{array}{l}\text { Full knowledge of material } \\
\text { content enables compliance with } \\
\text { product requirements. }\end{array}$ & \\
\hline $\begin{array}{l}\text { Reduced costs for waste disposal } \\
\text { through reuse options }\end{array}$ & $\begin{array}{l}\text { Reuse eliminates all costs related } \\
\text { to waste disposal. }\end{array}$ & \\
\hline
\end{tabular}

\section{Discussion}

This article had the objective of finding if $C E$ policies support $C E$ business models and the transition to a $\mathrm{CE}$ in the construction sector in the Nordics. In previous studies policies have been identified as a key driver for $\mathrm{CE}$ in the construction sector by setting the recycling targets for the sector, but little is known about how the policies can support the transition in practice. Local CE strategies or roadmaps toward CE have just recently been published, and experiences from the field have not yet been published in the Nordic countries.

The benchmarking of the national CE policy framework in Denmark, Finland, Norway, and Sweden showed that the construction sector was well represented in CE policy documents and that the national policy scene in all countries was somewhat similar in respect to target-setting and objectives. This can, however, be a mirror effect from EU CE policies for the construction sector, which are well transposed into the Nordic policy framework. The study mainly reviewed the key objectives of the policy documents, excluding enforcement and follow-up mechanisms, which ensure implementation in practice. In order to better understand how policies are put into practice, the enforcement and follow-up mechanisms could be reviewed, possibly in the light of performance indicators, showing the relationship between policy follow-up and CE implementation.The companies reviewed to identify links to the policies, as well as the companies interviewed for the identification of drivers and barriers, showed an inclination towards construction and end-of-life activities in the value chain, as well as waste prevention and recycling activities indicating their CE focus. The uneven distribution throughout the value chain and $C E$ focus is a result of where the $\mathrm{CE}$ activities of the construction sector are focused. The question remains as to whether the uneven distribution is a result of a policy landscape failing to support actors of the other phases of the value chain. Still, the uneven representation may be a bias, and forthcoming studies should emphasize either a better distribution, to correct this bias, or investigate the reason behind this bias.

Of the three key policies used by municipalities to facilitate the transition to a $\mathrm{CE}$, i.e., planning, requirements for sustainable constructions, and requirements for public procurement, only GPP was mentioned in the interviews as a policy supporting the CE-focused businesses. This does not exclude the other policies from being efficient in facilitating the transition. Planning and requirements for sustainable construction are elements of an early planning stage, whereas many of the interviewed companies are active later in the value chain and identified policies supporting their activities or phase of the value chain.

In order to fully understand the impacts of policies focusing on activities earlier in the value chain, other types of analyses need to be conducted, such as a comparison of regions with differing approaches to facilitating the transition.

Digitalization was identified as a key driver for CE. Many of the identified barriers address problems that could be solved with the successful implementation of online digital tools. Tools supporting communication on supply and demand combined with digital 
marketplaces for a business-to-business trade of reusable products and recovered materials could remove barriers related to material availability. Tools supporting traceability would highly support improved access to waste data, removing barriers related to concerns about the quality of the waste.

However, it was stated that the price and availability of recovered and reusable materials and components create major bottlenecks for reuse and recycling. It was expressed that virgin materials are cheaper and more easily accessible than their recovered alternatives. As long as the process for reuse and recycling is not streamlined and these products are not easily accessible, the CE business models will only represent an exotic alternative to the modus operandi.

In the assessment of links between CE business models and policies, it was found that many business opportunities benefit from the national and local policy landscape. Thus, putting theory into practice via CE policies can indeed drive the transition to a $\mathrm{CE}$ in the construction sector.

The study showed that, today, CE actors in the construction sector represent construction and end-of-life phases with a strong focus on waste management, such as waste prevention, reuse, and recycling. It was found that these actors benefit from the national and local policy landscape, especially policies that are implemented via GPP requirements. Additionally, this study showed that many of the barriers identified by the actors are such that they can be overcome via the successful implementation of online digital tools for trade and supporting traceability.

Author Contributions: Conceptualization, M.z.C.-R., M.W., A.O., T.F.A., C.J., P.J., E.R.W.; methodology, M.z.C.-R., M.W., A.O., T.F.A.; investigation, M.z.C.-R., M.W., A.O., T.F.A., C.J., P.J., E.R.W.; writing—original draft preparation, M.z.C.-R.; writing—review and editing, M.z.C.-R.; visualization, M.z.C.-R.; supervision, M.z.C.-R., M.W.; project administration, M.W.; funding acquisition, M.z.C.-R., M.W., A.O., T.F.A., C.J., P.J., E.R.W. All authors have read and agreed to the published version of the manuscript.

Funding: This research was funded by the Nordic Working Group for Circular Economy (NCE) under the Nordic Council of Ministers.

Conflicts of Interest: The authors declare no conflict of interest.

\section{Appendix A}

Table A1 shows the reviewed local CE policy documents with a section or targets dedicated to the construction sector.

Table A1. Reviewed local CE policy documents with a section or targets dedicated to the construction sector.

\begin{tabular}{|c|c|c|c|c|c|c|c|}
\hline \multirow{2}{*}{ Country } & \multirow{2}{*}{ Title and Reference } & \multirow{2}{*}{$\begin{array}{c}\text { Key Focus Areas in Respect to } \\
\text { Construction Sector }\end{array}$} & \multicolumn{5}{|c|}{ CE Criteria Focus* } \\
\hline & & & 1. & 2. & 3. & 4. & 5. \\
\hline DK & $\begin{array}{l}\text { Climate strategy and climate plan } \\
\text { 2016-2020, Aarhus } \\
\text { municipality [71] }\end{array}$ & $\begin{array}{l}\text { Energy-efficient renovation of existing building } \\
\text { stock, green transition, and sustainability in } \\
\text { building projects. }\end{array}$ & & & $\mathrm{x}$ & $\mathrm{x}$ & \\
\hline DK & $\begin{array}{l}\text { Environmental and energy efficient } \\
\text { construction in Aarhus } \\
\text { municipality [72] }\end{array}$ & $\begin{array}{l}\text { Requirements and recommendations for } \\
\text { municipal building work, aiming to make } \\
\text { buildings as sustainable as possible. }\end{array}$ & & $\mathrm{x}$ & $\mathrm{x}$ & & $\mathrm{x}$ \\
\hline DK & $\begin{array}{l}\text { Copenhagen Resource and waste } \\
\text { management plan } 2024 \text { [73] }\end{array}$ & $\begin{array}{l}\text { The plan presents initiatives related to the reuse of } \\
\text { construction materials from the city's properties } \\
\text { and cleaner recycling of C\&DW. }\end{array}$ & & $\mathrm{x}$ & $\mathrm{x}$ & & \\
\hline DK & $\begin{array}{l}\text { Circular economy Handbook for } \\
\text { the construction sector in } \\
\text { Copenhagen [70] }\end{array}$ & $\begin{array}{l}\text { Avoid using virgin non-renewable and } \\
\text { non-recyclable raw materials, to become more } \\
\text { resource-conscious and to increase the reuse and } \\
\text { recycling of waste. }\end{array}$ & $x$ & $\mathrm{x}$ & $x$ & $\mathrm{x}$ & $\mathrm{x}$ \\
\hline
\end{tabular}


Table A1. Cont.

\begin{tabular}{|c|c|c|c|c|c|c|c|}
\hline \multirow{2}{*}{ Country } & \multirow{2}{*}{ Title and Reference } & \multirow{2}{*}{$\begin{array}{l}\text { Key Focus Areas in Respect to } \\
\text { Construction Sector }\end{array}$} & \multicolumn{5}{|c|}{ CE Criteria Focus * } \\
\hline & & & 1. & 2. & 3. & 4. & 5. \\
\hline DK & $\begin{array}{l}\text { Environment in construction and } \\
\text { civil engineering 2016, Copenhagen } \\
\text { municipality [74] }\end{array}$ & $\begin{array}{l}\text { Environmental requirements to help implement a } \\
\text { number of political strategies related to CE. }\end{array}$ & & $\mathrm{x}$ & $x$ & & $\mathrm{x}$ \\
\hline DK & Bormholm climate strategy [75] & $\begin{array}{l}\text { The strategy presents goals for the building and } \\
\text { demolition sector, e.g., the goal of renovating } \\
\text { buildings sustainably by using sustainably } \\
\text { produced materials or reused materials. }\end{array}$ & & $\mathrm{x}$ & $\mathrm{x}$ & & \\
\hline DK & Bornholm waste strategy [76] & $\begin{array}{l}\text { Transposing the Danish waste and CE policies into } \\
\text { the national strategy. Including measures for } \\
\text { construction waste. }\end{array}$ & & $\mathrm{x}$ & $\mathrm{x}$ & & \\
\hline DK & $\begin{array}{l}\text { Kolding kommune Waste } \\
\text { management plan 2019-2024 [77] }\end{array}$ & $\begin{array}{l}\text { The plan presents goals and activities related to } \\
\text { the prevention and effective utilization of waste. } \\
\text { With respect to C\&DW, the municipality will } \\
\text { upgrade the effort for increased sorting and } \\
\text { removal of contaminated C\&DW. }\end{array}$ & & $\mathrm{x}$ & $\mathrm{x}$ & & \\
\hline $\mathrm{NO}$ & $\begin{array}{l}\text { Oslo municipality as a leading } \\
\text { environmental city [78] }\end{array}$ & $\begin{array}{l}\text { One focus area is circular economy in buildings, } \\
\text { aiming for emission-free and waste-free } \\
\text { construction sites, increased emphasis on reuse } \\
\text { and recycling and improving management of } \\
\text { existing building stock. }\end{array}$ & & $\mathrm{x}$ & $\mathrm{x}$ & & $\mathrm{x}$ \\
\hline FI & Carbon neutral Helsinki 2035 [69] & $\begin{array}{l}\text { In the strategy, Helsinki presents } 58 \text { actions to } \\
\text { achieve emissions reduction targets through } \\
\text { construction and buildings. }\end{array}$ & & $\mathrm{x}$ & $\mathrm{x}$ & $\mathrm{x}$ & \\
\hline $\mathrm{Fi}$ & Turku Climate Plan 2029 [79] & $\begin{array}{l}\text { Sustainable construction is developed and } \\
\text { promoted extensively in the entire city area. Using } \\
\text { wood as building material is promoted. }\end{array}$ & & & $x$ & $\mathrm{x}$ & \\
\hline FI & Vantaa CE plan [80] & $\begin{array}{l}\text { Target to become carbon-neutral by } 2030 \text {. Specific } \\
\text { targets for the construction sector }\end{array}$ & $\mathrm{x}$ & $\mathrm{x}$ & $x$ & $\mathrm{x}$ & \\
\hline $\mathrm{Fi}$ & $\begin{array}{l}\text { Kuopio resource efficiency } \\
\text { programme [81] }\end{array}$ & $\begin{array}{l}\text { Increase energy efficiency and sustainability } \\
\text { in construction. }\end{array}$ & & & $\mathrm{x}$ & & $\mathrm{x}$ \\
\hline $\mathrm{Fi}$ & $\begin{array}{l}\text { Development and sustainability } \\
\text { agenda for Åland [82] }\end{array}$ & $\begin{array}{l}\text { The CE principles of Aland in relation to the } \\
\text { construction sector are increasing recycling and } \\
\text { using timber grown on Åland in the } \\
\text { construction industry }\end{array}$ & & & $\mathrm{x}$ & $\mathrm{x}$ & \\
\hline SE & $\begin{array}{l}\text { Procurement requirements for } \\
\text { circular flows in the construction } \\
\text { and demolition process. The city of } \\
\text { Gothenburg. [83] }\end{array}$ & $\begin{array}{l}\text { The city of Gothenburg has developed } \\
\text { procurement requirements for circular flows in the } \\
\text { construction and demolition process }\end{array}$ & & & $\mathrm{x}$ & & \\
\hline SE & $\begin{array}{l}\text { Skåne region: guidelines to } \\
\text { minimize the waste from } \\
\text { construction sites [84] }\end{array}$ & $\begin{array}{l}\text { Guidelines to minimize the waste from } \\
\text { construction activities. }\end{array}$ & & $\mathrm{x}$ & & & \\
\hline SE & $\begin{array}{l}\text { Local roadmap for a climate-neutral } \\
\text { construction and civil engineering } \\
\text { sector in Malmö } 2030 \text { [85] }\end{array}$ & $\begin{array}{l}\text { The roadmap includes targets such as resource } \\
\text { efficiency and climate-neutral building materials. }\end{array}$ & & $\mathrm{x}$ & $x$ & $x$ & \\
\hline SE & $\begin{array}{l}\text { Climate strategic program for } \\
\text { Gothenburg [86] }\end{array}$ & $\begin{array}{l}\text { Gothenburg aims to become one of the most } \\
\text { progressive cities in the world in the rectification } \\
\text { of climate-related problems. }\end{array}$ & & $x$ & $x$ & $x$ & $x$ \\
\hline
\end{tabular}

* 1 reducing use of resources; 2 . waste prevention; 3 . increasing recycling rates; 4 . use of biobased/renewable materials; 5 . use of recyclable materials. 


\section{Appendix B}

Table A2 shows the business focus of the actors chosen for the assessment of how policies influence the implementation of CE concepts at different levels in the construction sector in the Nordics

Table A2. Business focus of the companies chosen for the assessment of how policies influence the implementation of $\mathrm{CE}$ concepts at different levels in the construction sector in the Nordics.

\begin{tabular}{|c|c|}
\hline Case nr. & Business Focus \\
\hline 1. & $\begin{array}{l}\text { Technology development for a more efficient pre-demolition inventory. The collected information enables a more } \\
\text { efficient dismantling of valuable materials and products, and supports selective demolition. }\end{array}$ \\
\hline 2. & $\begin{array}{l}\text { Development of a digital marketplace for the trade of reusable construction products and furniture. Users can register } \\
\text { materials and inventory planned for demolition to make them available to others. }\end{array}$ \\
\hline 3. & $\begin{array}{l}\text { Using wood waste from renovation and demolition projects in the production of high-value products. High focus on } \\
\text { finding feedstock that can be traced to ensure material quality and safety. }\end{array}$ \\
\hline 4. & $\begin{array}{l}\text { Reuse and closed loop recycling of C\&DW. Focus on finding a self-sustaining system for the collection and recycling of } \\
\text { flat glass. }\end{array}$ \\
\hline 5. & $\begin{array}{l}\text { Closed loop recycling of C\&DW. Focus on the recycling of plasterboards by developing a new business model and } \\
\text { streamline the reverse logistics. }\end{array}$ \\
\hline 6. & Construction of an office building with a high focus on environmental sustainability in the building's design \\
\hline 7. & $\begin{array}{l}\text { Dismantling of interior products prior to demolition, focusing on reusable products and materials that have a } \\
\text { second-hand value. }\end{array}$ \\
\hline 8. & $\begin{array}{l}\text { Policy and legislation-removal of legislative barriers for recycling. Recyclers actively involved in the revision of } \\
\text { legislation, aiming to remove barriers for the use of secondary raw materials in construction. }\end{array}$ \\
\hline 9. & $\begin{array}{l}\text { Modular demountable wooden constructions intended for a temporary and/or unknown length of use. Easy to } \\
\text { reconstruct, including possibilities for changes in size and intended use. }\end{array}$ \\
\hline 10. & $\begin{array}{l}\text { Closed loop recycling of C\&DW. Certified recycling of concrete waste in new concrete allowing closed loops and } \\
\text { full traceability. }\end{array}$ \\
\hline 11 & $\begin{array}{l}\text { Municipal construction projects with a CE focus. The developer unit is responsible for the construction of public } \\
\text { buildings; the CE efforts have resulted in a number of CE-focused construction projects. }\end{array}$ \\
\hline 12. & $\begin{array}{l}\text { Facilitate the selling of building products for reuse. The company hosts a digital marketplace for the trade of reusable } \\
\text { building products and furniture. }\end{array}$ \\
\hline 13. & $\begin{array}{l}\text { Collection of surplus materials and products from construction sites; resell to customers. These products and materials } \\
\text { have traditionally ended up as waste at the construction sites. }\end{array}$ \\
\hline 14. & $\begin{array}{l}\text { Development of digital process tools to track the generation of waste at construction sites and optimize the collaboration } \\
\text { between partners in planning, procurement, and logistics activities with the aim to achieve waste-free construction sites. }\end{array}$ \\
\hline
\end{tabular}

\section{References}

1. Ellen MacArthur Foundation. Towards a Circular Economy: Business Rationale for an Accelerated Transition. Available online: https:/ / www.ellenmacarthurfoundation.org/publications/towards-a-circular-economy-business-rationale-for-anaccelerated-transition (accessed on 26 May 2021).

2. Hradil, P.; Talja, A.; Wahlström, M.; Huuhka, S.; Lahdensivu, J.; Pikkuvirta, J. Re-Use of Structural Elements; VTT Technical Research Centre of Finland: Espoo, Finland, 2014; ISBN 9789513881979.

3. Wahlström, M.; Bergmans, J.; Teittinen, T.; Bachér, J.; Smeets, A.; Paduart, A. Construction and Demolition Waste: Challenges and Opportunities in a Circular Economy. Available online: https: / www.eionet.europa.eu/etcs/etc-wmge/products/etc-reports/ construction-and-demolition-waste-challenges-and-opportunities-in-a-circular-economy (accessed on 26 May 2021).

4. European Commission. Construction and Demolition Waste. Available online: https:/ /ec.europa.eu/environment/topics/wasteand-recycling/construction-and-demolition-waste_en (accessed on 28 May 2021).

5. EUROSTAT. Recovery Rate of Construction and Demolition Waste [Cei_wm040]. Available online: http:/ / appsso.eurostat.ec. europa.eu/nui/show.do (accessed on 28 May 2021).

6. Gillabel, J.; Manshoven, S.; Grossi, F.; Mortensen, L.F.; Coscieme, L. Business Models in a Circular Economy. Available online: https:/ / www.eionet.europa.eu/etcs/etc-wmge/products/business-models-in-a-circular-economy (accessed on 28 May 2021). 
7. Williams, R.; Artola, I.; Beznea, A.; Nicholls, G. Emerging Challenges of Waste Management in Europe Limits of RecyclingFinal Report. Available online: https://trinomics.eu/wp-content/uploads/2020/06/Trinomics-2020-Limits-of-Recycling.pdf (accessed on 26 May 2021).

8. Wahlström, M.; zu Castell-Rüdenhausen, M.; Hradil, P.; Hauge-Smith, K.; Oberender, A.; Ahlm, M.; Götbring, J.; Hansen, J.B. Improving Quality of Construction \& Demolition Waste-Requirements for Pre-Demolition Audit; Nordic Council of Ministers: Copenhagen, Denmark, 2019; ISBN 978-92-893-6014-2.

9. Deloitte; BRE; Directorate-General for Environment (European Commission); FCT.; ICEDD.; RPS.; VTT. Resource Efficient Use of Mixed Wastes Improving Management of Construction and Demolition Waste_Final Report; EU Publications Office: Luxembourg, 2017; ISBN 978-92-79-76478-3.

10. Kirchherr, J.; Hekkert, M.; Bour, R.; Huijbrechtse-Truijens, A.; Kostense-Smit, E.; Muller, J. Breaking the Barriers to the Circular Economy. Available online: https:/ / circulareconomy.europa.eu/platform/sites/default/files/171106_white_paper_breaking_ the_barriers_to_the_circular_economy_white_paper_vweb-14021.pdf (accessed on 26 May 2021).

11. Miljøstyrelsen. Establishing Effective Markets for Secondary Building Materials; Miljøstyrelsen: Copenhagen, Denmark, 2019; ISBN 978-87-7038-052-2.

12. Hiser Project. Available online: http:/ / hiserproject.eu/ (accessed on 26 May 2021).

13. IRCOW Project. The IRCOW Project. Available online: https://www.europeandemolition.org/industry/projects/ircow (accessed on 26 May 2021).

14. Høibye, L.; Sand, H. Circular Economy in the Nordic Construction Sector. Identification and Assessment of Potential Policy Instruments That Can Accelerate a Transition toward a Circular Economy; Nordic Council of Ministers: Copenhagen, Denmark, 2018; ISBN 978-92-893-5489-9.

15. Munck-Kampmann, I.E.; Werther, I.; Christensen, L.H. Recycling in the Circular Economy-How to Improve the Recycling Markets for Construction Materials, Biowaste, Plastics and Critical Metals. Available online: http://norden.diva-portal.org/ smash/get/diva2:1269435/FULLTEXT01.pdf (accessed on 26 May 2021).

16. Alhola, K.; Salmenperä, H.; Ryding, S.; Busch, N.J. Circular Public Procurement in the Nordic Countries; Nordic Council of Ministers: Copenhagen, Denmark, 2017; ISBN 978-92-893-4900-0.

17. European Environment Agency. Construction and Demolition Waste: Challenges and Opportunities in a Circular Economy. Available online: https:/ / www.eea.europa.eu/publications/construction-and-demolition-waste-challenges/construction-anddemolition-waste-challenges (accessed on 26 May 2021).

18. Afshari, A.R.; Górecki, J. Circular Economy in Construction Sector. In Proceedings of the CEPPIS 2019: International scientific conference Civil Engineering: Present Problems, Innovative Solutions, Bydgoszcz, Poland, 22 May 2019.

19. Esa, M.R.; Halog, A.; Rigamonti, L. Developing Strategies for Managing Construction and Demolition Wastes in Malaysia Based on the Concept of Circular Economy. J. Mater. Cycles Waste Manag. 2017, 19, 1144-1154. [CrossRef]

20. Akanbi, L.; Oyedele, L.; Delgado, J.M.D.; Bilal, M.; Akinade, O.; Ajayi, A.; Mohammed-Yakub, N. Reusability Analytics Tool for End-of-Life Assessment of Building Materials in a Circular Economy. World J. Sci. Technol. Sustain. Dev. 2019, 16. [CrossRef]

21. Wahlström, M.; zu Castell-Rüdenhausen, M.; Astrup, T.F.; Oberender, A.; Jensen, C.; Johansson, P.; Wærner, E.R. Strategies and Methods for Implementing CE in Construction Activities in the Nordic Countries; Nordic Council of Ministers: Copenhagen, Denmark, 2021; ISBN 978-92-893-6930-5.

22. European Commission. Directive 2008/98/EC of the European Parliament and of the Council of 19 November 2008 on Waste and Repealing Certain Directives; European Commission: Brussels, Belgium, 2008.

23. European Commission. Communication from the Commission to the European Parliament, the Council, the European Economic and Social Committee and the Committee of the Regions. A New Circular Economy Action Plan for a Cleaner and More Competitive Europe; European Commission: Brussels, Belgium, 2020.

24. European Commission. Communication from the Commission to the European Parliament, the Council, the European Economic and Social Committee and the Committee of the Regions. Closing the Loop-An EU Action Plan for the Circular Economy; European Commission: Brussels, Belgium, 2015.

25. European Commission. Communication from the Commission to the European Parliament, the Council, the European Economic and Social Committee and the Committee of the Regions. The European Green Deal; European Commission: Brussels, Belgium, 2019.

26. European Commission. Communication from the Commission to the European Parliament, the Council, the European Economic and Social Committee and the Committee of the Regions. A Renovation Wave for Europe-Greening Our Buildings, Creating Jobs, Improving Lives; European Commission: Brussels, Belgium, 2020.

27. European Commission. Level(s) European Framework for Sustainable Buildings. Available online: https://ec.europa.eu/ environment/topics / circular-economy / levels_en (accessed on 28 May 2021).

28. BRE Group. Building Back Better with BREEAM: Supporting the Green Recovery. Available online: https://www.breeam.com/ (accessed on 28 May 2021).

29. U.S. Green Building Council. LEED Rating System. Available online: https:/ /www.usgbc.org/leed (accessed on 28 May 2021).

30. EUROSTAT. Recovery Rate of Construction and Demolition Waste [Cei_wm040] Metadata. Available online: https:/ / ec.europa. eu/eurostat/cache/metadata/en/cei_wm040_esmsip2.htm (accessed on 28 May 2021). 
31. European Commission. Commission Implementing Decision (EU) 2019/1004 of 7 June 2019 Laying down Rules for the Calculation, Verification and Reporting of Data on Waste in Accordance with Directive 2008/98/EC of the European Parliament and of the Council and Repealing Commission Implementing Decision C(2012) 2384; European Commission: Brussels, Belgium, 2019.

32. Ellen MacArthur Foundation. City Governments and Their Role in Enabling a Circular Economy Transition. An Overview of Urban Policy Lever. Available online: https://www.ellenmacarthurfoundation.org/assets/downloads/CE-in-Cities_PolicyLevers_Mar19.pdf (accessed on 28 May 2021).

33. Miljøministeriet. Handlingsplan for Cirkulær Økonomi. National Plan for Forebyggelse Og Håndtering Af Affald 2020-2032; Miljøministeriet: Copenhagen, Denmark, 2020; ISBN 978-87-7120-068-3.

34. Finnish Government. Government Decree on Waste (179/2012); Finnish Government: Helsinki, Finland, 2012.

35. Norwegian Government. Regulations on Technical Requirements for Building Works (Technical Regulations); Norwegian Government: Oslo, Norway, 2017.

36. Swedish Government. Avfallsförordning (2020:614); Swedish Government: Stockholm, Sweden, 2020.

37. European Commission. Regulation (EU) No 305/2011 of the European Parliament and of the Council of 9 March 2011 Laying down Harmonised Conditions for the Marketing of Construction Products and Repealing Council Directive 89/106/EEC; European Commission: Brussels, Belgium, 2011.

38. European Commission. Communication from the Commission to the European Parliament, the Council, the European Economic and Social Committee and the Committee of the Regions. Public Procurement for a Better Environment. COM(2008) 400 Final; European Commission: Brussels, Belgium, 2008.

39. European Commission. Buying Green! A Handbook on Green Public Procurement, 3rd ed.; European Commision: Brussels, Belgium, 2016; ISBN 978-92-79-56848-0.

40. European Commission. EU GPP Criteria; Directorate-General for Environment: Brussels, Belgium, 2021.

41. KEINO. Competence Centre for Sustainable and Innovative Public Procurement. Available online: https://www.hankintakeino, fi/en (accessed on 28 May 2021).

42. Kuittinen, M. Kiertotalous Julkisissa Purkuhankkeissa. Hankintaopas; Finnish Ministry of the Environment: Helsinki, Finland, 2019; ISBN 978-952-361-038-5.

43. European Commission. Communication from the Commission to the European Parliament, the Council, the European Economic and Social Committee and the Committee of the Regions. On a Monitoring Framework for the Circular Economy \{SWD(2018) 17 Final\}; European Commission: Brussels, Belgium, 2018.

44. EUROSTAT. Circular Economy Indicators. Available online: https:/ / ec.europa.eu/eurostat/web/circular-economy /indicators/ monitoring-framework (accessed on 28 May 2021).

45. Moraga, G.; Huysveld, S.; Mathieux, F.; Blengini, G.A.; Alaerts, L.; Van Acker, K.; de Meester, S.; Dewulf, J. Circular Economy Indicators: What Do They Measure? Resour. Conserv. Recycl. 2019, 146, 452-461. [CrossRef] [PubMed]

46. Finnish Ministry of the Environment. From Recycling to a Circular Economy National Waste Plan to 2023; Finnish Ministry of the Environment: Helsinki, Finland, 2018; ISBN 978-952-11-4796-8.

47. Norwegian Government. Avfall Som Ressurs-Avfallspolitikk Og Sirkulær Økonomi. Available online: https://www.regjeringen. no/no/dokumenter/meld.-st.-45-20162017/id2558274/ (accessed on 27 May 2021).

48. Naturvårdsverket. Att Göra Mer Med Mindre Nationell Avfallsplan Och Avfallsförebyggande Program 2018-2023. Reviderad 2020; Naturvårdsverket: Stockholm, Sweden, 2020; ISBN 978-91-620-6946-9.

49. Miljøstyrelsen. Danmark Uden Affald. Ressourceplan for Affaldshåndtering 2013-2018; Miljøstyrelsen: Copenhagen, Denmark, 2014; ISBN 978-87-93178-55-7.

50. Danish Government. Danmark Uden Affald. Genanvend Mere-Forbrænd Mindre. Available online: https://mst.dk/media/mst/ Attachments/Ressourcestrategi_DK_web.pdf (accessed on 27 May 2021).

51. Danish Government. Danmark Uden Affald II. Strategi for Affaldsforebyggelse. Available online: https://mst.dk/media/90395/ danmark_uden_affald_ii_web_29042015.pdf (accessed on 27 May 2021).

52. Danish Government. Strategi for Cirkulær Økonomi. Mere Værdi Og Bedre Miljø Gennem Design, Forbrug Og Genanvendelse. Available online: https:/ / www.regeringen.dk/media/5626/strategi-for-cirkulaer-oekonomi_web.pdf (accessed on 27 May 2021).

53. Danish Government. Strategi for Intelligent Offentligt Indkøb. Available online: https://www.regeringen.dk/media/1278 /strategi_for_intelligent_offentligt_indkoeb.pdf (accessed on 27 May 2021).

54. The Danish Government. Plastik Uden Spild—Regeringens Plastikhandlingsplan. Available online: https://mfvm.dk/fileadmin/ user_upload/MFVM/Publikationer/NY_Regeringens_plastikhandlingsplan_full_version_FINAL_0123-2019.pdf (accessed on 27 May 2021).

55. Danish Ministry of Transport, Construction and Housing. Strategi for Digitalt Byggeri. Available online: https://www.trm.dk/ publikationer/2019/strategi-for-digitalt-byggeri/ (accessed on 27 May 2021).

56. Finnish Government. Uusi Suunta Ehdotus Kiertotalouden Strategiseksi Ohjelmaksi; Finnish Government: Helsinki, Finland, 2021; ISBN 978-952-383-642-6.

57. Finnish Ministry of Employment and the Economy; Finnish Ministry of the Environment. National Material Efficiency ProgrammeSustainable Growth through Material Efficiency; Finnish Ministry of Employment and the Economy: Helsinki, Finland, 2014; ISBN 978-952-227-830-2. 
58. Peuranen, E.; Hakaste, H. Rakentamisen Materiaalitehokkuuden Toimenpideohjelma; Finnish Ministry of the Environment: Helsinki, Finland, 2014; ISBN 978-952-11-4342-7.

59. Lehtonen, K. Purkutyöt_Opas Tekijöille Ja Teettäjille; Finnish Ministry of the Environment: Helsinki, Finland, 2019; ISBN 978-952-361-036-1.

60. Finnish Ministry of the Environment. Reduce and Refuse, Recycle and Replace. A Plastics Roadmap for Finland. Available online: https:/ / muovitiekartta.fi/userassets/uploads/2019/03/Reduce-and-refuse-recycle-and-replace.-A-Plastics-Roadmapfor-Finland.pdf (accessed on 27 May 2021).

61. Finnish Ministry of the Environment. Puurakentamisen Ohjelma. Available online: https://ym.fi/puurakentaminen (accessed on 27 May 2021).

62. NHP-nettverket. Nasjonal Handlingsplan for Bygg Og Anleggsavfall 2021-2023; NHP-nettverket: Tønsberg, Norway, 2021; ISBN 978-82-93777-03-8.

63. Norsk Industri. Sirkulær Økonomi-Industriens Hovedanbefalinger. Available online: https://www.norskindustri.no/siteassets/ dokumenter/horinger-og-notater/sirkular-okonomi---industriens-hovedanbefalinger-no.pdf (accessed on 27 May 2021).

64. Norwegian Government. Sirkulær Økonomi. Available online: https://www.regjeringen.no/no/tema/klima-og-miljo/ forurensning/sirkular-okonomi/id2700997/ (accessed on 27 May 2021).

65. Miljödepartementet. Cirkulär Ekonom-Strategi för Omställningen i Sverige. Available online: https://www.regeringen.se/4a3 baa/contentassets/619d1bb3588446deb6dac198f2fe4120/200814_ce_webb.pdf (accessed on 27 May 2021).

66. Byggföretagen. Resource and Waste Guidelines for Construction and Demolition. Available online: https://byggforetagen.se/ app/uploads/2020/02/Resource-and-waste-guidelines-2019.pdf (accessed on 27 May 2021).

67. Fossilfritt Sverige. Färdplan För Fossilfri Konkurrenskraft. Bygg-Och Anläggningssektorn. Available online: https: //fossilfrittsverige.se/wp-content/uploads/2020/10/ffs_bygg_anlaggningssektorn.pdf (accessed on 27 May 2021).

68. Näringsdepartementet. Inriktning För Träbyggande. Available online: https://www.regeringen.se/49ee7f/contentassets/37f078 02672c45078a20d3a375e82c25/20180626_inriktning-for-trabyggande.pdf (accessed on 27 May 2021).

69. City of Helsinki. The Carbon Neutral Helsinki 2035 Action Plan. Available online: https://www.hel.fi/static/liitteet/ kaupunkiymparisto/julkaisut/julkaisut/HNH-2035/Carbon_neutral_Helsinki_Action_Plan_1503019_EN.pdf (accessed on 27 May 2021).

70. Københavns Kommune. Byggeri Københavns Håndbog i Cirkulær Økonomi. Available online: https://www.kf.dk/media/2779 / haandbog-i-cirkulaer-oekonomi-byggeri-koebenhavn-3-udgave-24-marts-2021.pdf (accessed on 28 May 2021).

71. Aarhus Municipality. Go Green with Aarhus. Available online: https://gogreenwithaarhus.dk/ (accessed on 27 May 2021).

72. Aarhus Municipality. Miljø-Og Energirigtigt Byggeri Aarhus Kommune. Available online: https://www.aarhus.dk/media/2274 1/miljoe-og-energirigtig-byggeri-i-aarhus-kommune.pdf (accessed on 27 May 2021).

73. Københavns Kommune. Circular Copenhagen. Resource and Waste Management Plan 2024. Available online: https:// kk.sites.itera. dk/apps/kk_pub2/index.asp?mode=detalje\&id=1991 (accessed on 27 May 2021).

74. Københavns Kommune. Miljø i Byggeri Og Anlæg 2016. Available online: https://www.kk.dk/sites/default/files/ sustainability_in_construction_and_civil_works_2016.pdf (accessed on 27 May 2021).

75. Bornholm Kommune. Bright Green Island Visionen-Bornholmermålene Frem Mod 2035. Available online: http://www. brightgreenisland.dk/nyheder/Documents/PDF_BrightGreenIsland_vision2018_pdf.pdf (accessed on 27 May 2021).

76. Bornholm Kommune. Bornholm Showing the Way-Without Waste 2032. Available online: https://bofa.dk/wp-content/ uploads/2019/01/BOFA_mini-publikation_UK_A4_160119.pdf (accessed on 27 May 2021).

77. Kolding Kommune. Affaldsplan 2019-2024. Available online: https://www.kolding.dk/media/mnhhlffc/affaldsplan-2019-202 4_kolding-kommune_was.pdf (accessed on 27 May 2021).

78. Oslo Kommune. Oslo Som Miljøhovedstad. Available online: https://www.oslo.kommune.no/miljo-og-klima/oslo-sommiljohovedstad/\#! (accessed on 27 May 2021).

79. City of Turku. Turku Climate Plan 2029. Available online: https://www.turku.fi/sites/default/files/atoms/files//turku_ climate_plan_2029.pdf (accessed on 27 May 2021).

80. City of Vantaa. Vantaan Kiertotalouden Tiekartta 2019-2030. Available online: https://www.vantaa.fi/instancedata/ prime_product_julkaisu/vantaa/embeds/vantaawwwstructure/145955_Kiertotalouden_tiekartta_lopullinen.pdf (accessed on 27 May 2021).

81. City of Kuopio. Kuopio Resource Efficiency Programme. Available online: https://www.kuopio.fi/documents/7369547/758306 0/Kuopion+resurssiviisausohjelma/b9c68ee3-fb3a-492b-82ff-47ea882a0542 (accessed on 27 May 2021).

82. Ålands Landskapsregering. Development and Sustainability Agenda for Åland. Available online: https://www.regeringen.ax/ sites/www.regeringen.ax/files/attachments / page/development-and-sustainability-agenda-for-aland-2017-03-01.pdf (accessed on 27 May 2021).

83. City of Gothenburg. Upphandlingskrav För Cirkulära Flöden i Bygg-Och Rivningsprocessen. Available online: https: //goteborg.se/wps/wcm/connect/d0600675-8e9c-4522-9984-4783c65d9a07/Slutrapport+Upphandlingskrav+f\%C3\%B6r+ cirkul\%C3\%A4ra+fl\%C3\%B6den+i+bygg-+och+rivningsprocessen.pdf?MOD=AJPERES (accessed on 27 May 2020). 
84. Hållbar Utveckling Skåne. Verktyg För Att Minska Avfall Vid Nybyggnation. Available online: https://www.hutskane.nu/ projekt/verktyg-for-att-minska-avfall-vid-nybyggnation/ (accessed on 27 May 2021).

85. LFM30. Tillsammans Utvecklar vi En Klimatneutral Bygg-Och Anläggningssektor i Malmö. Available online: https://lfm30.se/ (accessed on 27 May 2021).

86. City of Gothenburg. Klimatstrategiskt Program För Göteborg. Available online: https://goteborg.se/wps/portal/start/ miljo/det-gor-goteborgs-stad/klimatstrategiskt-program/!ut/p/z1/04_Sj9CPykssy0xPLMnMz0vMAfljo8ziQw0NAi2cDB0 NLCwCzA08gxzdzU2M3Q38vcz0wwkpiAJKG-AAjgb6BbmhigAzNGH5/dz/d5/L2dBISEvZ0FBIS9nQSEh/ (accessed on 27 May 2021). 